\title{
Nuclear Receptors, Ligands and the Mammalian B Cell
}

\author{
Bart G. Jones ${ }^{1}$, Rhiannon R. Penkert ${ }^{1}{ }^{1}$, Sherri L. Surman ${ }^{1}$, Robert E. Sealy ${ }^{1}$ and \\ Julia L. Hurwitz ${ }^{1,2, *}$ \\ 1 Department of Infectious Diseases, St. Jude Children's Research Hospital, Memphis, TN 38105, USA; \\ bart.jones@stjude.org (B.G.J.); rhiannon.penkert@stjude.org (R.R.P.); sherri.surman@stjude.org (S.L.S.); \\ bob.sealy@stjude.org (R.E.S.) \\ 2 Department of Microbiology, Immunology and Biochemistry, University of Tennessee Health Science Center, \\ Memphis, TN 38163, USA \\ * Correspondence: julia.hurwitz@stjude.org
}

Received: 8 June 2020; Accepted: 8 July 2020; Published: 15 July 2020

\begin{abstract}
Questions concerning the influences of nuclear receptors and their ligands on mammalian $B$ cells are vast in number. Here, we briefly review the effects of nuclear receptor ligands, including estrogen and vitamins, on immunoglobulin production and protection from infectious diseases. We describe nuclear receptor interactions with the B cell genome and the potential mechanisms of gene regulation. Attention to the nuclear receptor/ligand regulation of $B$ cell function may help optimize B cell responses, improve pathogen clearance, and prevent damaging responses toward inert- and self-antigens.
\end{abstract}

Keywords: estrogen; vitamins; immunoglobulin; regulatory elements

\section{Nuclear Receptors, Ligands, and the Mammalian Cell}

The steroid/thyroid hormone nuclear receptors comprise a superfamily of transcription factors characterized by a DNA-binding domain (DBD), a ligand-binding domain (LBD), and a transactivation domain [1,2]. Type I receptors (including estrogen receptor (ER), glucocorticoid receptor (GR), progesterone receptor (PR), and androgen receptor (AR)) are typically homodimers, while type II receptors are typically heterodimers. Examples of type II receptors include retinoic acid receptor-retinoid $X$ receptor (RAR-RXR), vitamin D receptor-RXR (VDR-RXR) and thyroid receptor-RXR (TR-RXR). Multiple isoforms exist for the protein subunits. RXR proteins, for example, include $R X R \alpha, R X R \beta$, and $R X R \gamma$, each associated with different binding patterns and functions [1,3]. RAR proteins include $\operatorname{RAR} \alpha, \operatorname{RAR} \beta$, and $\operatorname{RAR} \gamma$. Ligands for the nuclear receptors, both natural and synthetic, are numerous. Examples include vitamin A metabolites (for RAR, RXR, and the peroxisome proliferator-activated receptor $\beta / \delta$ (PPAR $\beta / \delta$ ) [4]), 17- $\beta$ estradiol (for ER), progesterone (for PR), testosterone and dihydrotestosterone (for AR), 3,3',5,5' triiodo-L-thyroxine (for the thyroid receptor [TR]), and dexamethasone and prednisolone (for GR). The natural ligand for RXR remains a topic of debate. Although 9-cis retinoic acid has been discovered to bind RXR, this metabolite is difficult to detect in many mammalian tissues. Other possible natural ligands for RXR include unsaturated fatty acids such as docosahexaenoic acid, arachidonic acid and oleic acid [3].

The influences of nuclear receptors and their ligands on the mammalian cell are extraordinarily complex. Vitamin A, for example, signals the mammalian cell as soon as it reaches the plasma membrane [5]. Signals continue as vitamin traffics through the cell toward the nucleus, engaging numerous chaperones along the way. Receptors such as RXR also exhibit cytoplasmic functions, distinct from their activities as transcription factors. Within the nucleus, when vitamin A serves as 
a ligand for its nuclear receptors, it can instruct conformational changes [1,6-9]. Ligand-bound and unbound receptors, when associated with DNA (either by direct DNA-protein interactions or by DNA tethering via protein-protein interactions), can recruit, inhibit, and interact with other transcription factors to instruct DNA configurations and gene expression patterns [1].

Class II heterodimers have been further characterized as 'permissive' or 'non-permissive'. The term 'permissive' was attributed to heterodimers that were activated in a controlled setting by ligand binding either to RXR, its partner protein (e.g., PPAR), or both. The term 'non-permissive' was attributed to heterodimers that could not be activated by ligand binding to RXR alone. Permissive receptor proteins include PPAR, liver $X$ receptor (LXR), farnesoid $X$ receptor (FXR), pregnane $X$ receptor (PXR) and constitutive androstane receptor (CAR), each of which is responsive to diet-derived lipids. Non-permissive receptor proteins include RAR, VDR, and TR [1,10-12].

A survey of nuclear receptor DNA-binding patterns has revealed consensus nucleotide motifs (response elements) to which each receptor preferentially binds. As examples, type II receptors often bind two tandem, hexad half-sites, RG(G/T)TCA, separated by a short spacer [13]. RAR-RXR binding to DNA shows a preference for spacers of size 5 (direct repeat 5, DR5) or 2 (DR2), whereas VDR-RXR binding to DNA shows a preference for spacers of size 3 (DR3) and TR-RXR shows a preference for spacers of size 4 (DR4) [1]. Occasionally, the receptors bind individual half-sites or half-sites separated by unusually long spacers. RXR can also function as a self-sufficient homodimer, able to bind a DR1 element. The estrogen receptor often binds a palindromic motif GGTCAnnnTGACC [14,15]. These binding patterns are far from absolute and binding is often observed at sites that lack a canonical sequence $[1,7,9,16-29]$. Nuclear receptor cross-regulation is supported by receptor sharing of (i) protein partners (RXR is shared among the type II receptors), (ii) ligands (e.g., retinol binds RAR-RXR and PPAR-RXR), and (iii) DNA binding sites.

The outcome of nuclear receptor binding to DNA is difficult to predict due to the high complexity of protein-DNA complexes. For example, the estrogen regulation of the GREB1 gene involves ER $\alpha$ and RNA polymerase II (RNA Pol II) binding to three different estrogen response elements (ERE) within a $20 \mathrm{~kb}$ region and DNA looping that associates EREs with the gene's transcriptional start site [30,31].

\section{Antibody Expression by the Mature B Cell}

In the developing fetus, the site of mammalian B cell development is the yolk sac. Post-birth, conventional B cells develop in the bone marrow, dependent on bone marrow stroma. Stem cells progress through multiple stages of B cell development. At the pro B cell stage, gene rearrangements are initiated in the immunoglobulin heavy chain locus. Each B cell undergoes unique D-J and V-DJ gene rearrangements with the excision of intervening sequences to create a V-D-J coding sequence. At the pre-B cell stage, the transcription of V-D-J-C mRNA sequences and RNA splicing yield a $\mu$ heavy chain protein that can be detected in the cytoplasm or in combination with a surrogate light chain on the $B$ cell surface. In Pre-B cells, there is also a rearrangement of $\mathrm{V}$ and J genes within the immunoglobulin light chain loci (ког $\lambda$ ). Once the V-J-C light chains are expressed, two identical heavy chains and two identical light chains join to produce the classical immunoglobulin M (IgM) molecule, now advancing the cell to the immature B cell stage. After these antigen-independent processes occur in the bone marrow, the cells move to the periphery and develop into mature B cells (also called naïve B cells) expressing IgM and immunoglobulin D (IgD) via alternate RNA splicing [32]. B cells are activated when antigen or mitogen engages their cell surface antibodies, at which time $B$ cells proliferate and can mature to antibody-secreting plasma cells and/or memory cells. While B cells are best known for antibody production, they can also regulate other cells of the immune system [33].

After activation, the B cells may undergo somatic mutation and may also switch to immunoglobulin isotypes G, E, and A (IgG, IgE or IgA) by class switch recombination (CSR). The CSR process loops DNA in the immunoglobulin heavy chain locus, cuts DNA at the switch sites, deletes $C \mu, C \delta$ and other intervening sequences, and re-ligates DNA to reposition V-D-J near the $C \gamma, C \varepsilon$, or $C \alpha$ genes. The mechanism of CSR begins with the production of sterile transcripts by RNA Pol II, initiated upstream 
of the targeted switch sites. Polymerase stalls in the switch regions and recruits activation-induced cytidine deaminase (AID). AID converts cytidine to uracil, followed by the uracil DNA glycosylase (UNG)-mediated removal of uracil. Then, the DNA is cleaved by apurinic/apyrimidinic endonucleases, and non-homologous end joining completes the process [34].

Regulatory regions have been defined that influence immunoglobulin expression and CSR. In mice, the $3^{\prime}$ regulatory region ( $3^{\prime} R R$ ) includes multiple DNase I hypersensitive sites (hs $3 a$, hs1,2, hs $3 b$, and hs4) with enhancer activity, situated downstream of $C \alpha$. The $3^{\prime} R R$ interacts in loop formation with $\mathrm{E} \mu$ (a promoter/enhancer upstream of $\mathrm{C} \mu$ ), and switch regions. When the $3^{\prime} R R$ is absent, the mice express low levels of IgM and are deficient in CSR [35-38]. The hs1,2 sequence is of particular interest, because polymorphisms in this region in humans associate with an increased risk of systemic lupus erythematosus (lupus), a disease with a 9:1 female:male ratio [39].

\section{Sex and the Immune Response}

The immune responses of males and females differ [40-46]. Females generally express more total serum antibodies than males. Females also respond better to influenza virus vaccines and infections compared to males, both in mice and humans [47-49]. In humans, estrogen levels have been correlated with IgG responses toward an influenza virus vaccine [50]. Today, there is an unprecedented pandemic of SARS-CoV-2 infections and consequent COVID-19 disease. The influences of sex on this disease are already evident in that males suffer significantly more than females [51,52].

The heightened immune response in females compared to males is not always evident and does not always provide benefit. In fact, males exhibit better responses toward pneumococcus antigens compared to females [48]. Moreover, females often suffer higher frequencies of auto-immune disease compared to males. As noted above, there is a significant female predominance of lupus [53]. When females are pregnant and estrogen levels are extremely high, auto-immune diseases like lupus can be life-threatening [54,55]. Human females additionally suffer from asthma more than males, coincident with increased estrogen levels at the time of female puberty [56].

Using a mouse model for lupus (females of the strain NZM2410), Sven et al. described protection against autoimmune disease upon the knock-out of normal ER $\alpha$ expression (although conflicting results have been described $[57,58]$ ). In small animal and tissue culture settings, supplemental estrogen increased the antibody levels, including antibodies against self-antigens such as cardiolipin [48,56,59-64]. Whereas estrogen enhanced the immunoglobulin expression by human peripheral blood mononuclear cells (PBMC), immunoglobulin production was reduced in the presence of testosterone [64,65]. In a mouse model of allergen-induced dermatitis, an estrogen inhibitor reduced allergen-specific IgG1, IgG2a and IgE, as well as clinical disease symptoms [66].

\section{Vitamin D and the Immune Response}

Vitamin D is ingested from plant (D2) or animal (D3) sources including dairy products (often vitamin fortified) and fish. Vitamin D is also synthesized when 7-dehydrocholesterol in the skin is converted to cholecalciferol upon exposure to sunlight (ultra violet B (UVB)) rays) [67]. In the liver, 25-hydroxylase converts cholecalciferol to 25 hydroxy-vitamin $\mathrm{D}(25(\mathrm{OH}) \mathrm{D}$, also termed calcidiol), a common metabolite in the blood. Escorts for $25(\mathrm{OH}) \mathrm{D}$ in the blood include the vitamin $\mathrm{D}$ binding protein (VDBP) and albumin. Polymorphisms in VDBP are common and may influence the efficiency of vitamin $\mathrm{D}$ uptake into tissues. Within tissues, $1 \alpha$ hydroxylase converts $25(\mathrm{OH}) \mathrm{D}$ to the end-metabolite 1,25 dihydroxy vitamin $\mathrm{D}\left(1,25(\mathrm{OH})_{2} \mathrm{D}\right.$, also termed calcitriol). The Office of Dietary Supplements (ODS) in the United States recommends a vitamin D daily intake (recommended dietary allowance, RDA) of $10 \mu \mathrm{g}$ ( 400 international units (IU)) for infants, $15 \mu \mathrm{g}$ ( 600 IU) for individuals of ages 1-70 years, and $20 \mu \mathrm{g}(\sim 800 \mathrm{IU})$ for individuals of ages $>70$ years (ods.od.nih.gov). Debates continue as to the appropriate levels of vitamin D in blood, but most scientists agree that blood levels of $>30 \mathrm{ng} / \mathrm{mL}$ vitamin D will support a healthy immune system. 
Vitamin D deficiencies and insufficiencies are recognized throughout the world and affect numerous mammalian systems and conditions including lung development and pregnancy [68]. Nutritional deficiencies occur in both developed and developing countries. In the developed world, vitamin deficiencies are exacerbated by reduced sun exposures and emerging food deserts in low income communities [69].

Vitamin D provides significant benefit to the immune response, both adaptive and innate. For example, when macrophages are infected with $M$ tuberculosis, they produce high levels of $1,25(\mathrm{OH})_{2} \mathrm{D}$ and effectively kill the pathogen. Vitamin D can also play an important regulatory role by dampening allergic reactions such as asthma, eczema and food allergies or autoimmune disorders such as multiple sclerosis or diabetes mellitus [70,71]. In humans, serum levels of $25(\mathrm{OH}) \mathrm{D}$ correlate with total serum IgM and IgG3 [72] and correlate with an improved control of respiratory diseases including tuberculosis [73-75].

\section{Vitamin A and the Immune Response}

Vitamin A can be ingested in the form of provitamin A carotenoids from plant foods including green, orange and yellow vegetables such as carrots and sweet potatoes or retinoids (preformed vitamin A) from foods including dairy products, fish, poultry, and other meats (particularly liver). As for vitamin D, the RDA for vitamin A is a topic of continued debate. The ODS recommends a daily intake of vitamin A in retinol activity equivalents (RAE) as approximately $400-500 \mu \mathrm{g}$ for infants, $300 \mu \mathrm{g}$ for individuals of ages 1-3 years, $400 \mu \mathrm{g}$ for individuals of ages 4-8 years, $600 \mu \mathrm{g}$ for individuals of ages 9-13 years, and 700-1300 $\mu \mathrm{g}$ for individuals of ages $>14$ years depending on sex, pregnancy, and breastfeeding ( $0.3 \mu \mathrm{g}$ RAE $=1$ international unit (IU) retinol, ods.od.nih.gov). Blood levels of retinol defined as 'deficient' or 'insufficient' are also debated. Often, vitamin A deficiency (VAD) is defined as $<0.7 \mu \mathrm{M}(\sim 20 \mu \mathrm{g} /$ deciliter $(\mathrm{dL}))$ retinol and vitamin A insufficiency is defined as $\geq 0.7$, but $<1.05 \mu \mathrm{M}$ retinol. Vitamin A is usually stored in the liver in the form of retinyl esters and traffics through the blood as retinol, chaperoned by retinol binding protein (RBP) in a 1:1 molar ratio. RBP is also bound to a serum protein transthyretin (TTR) which assists retinol delivery to peripheral tissues. Other chaperones for vitamin A in blood or lymph include albumin and chylomicrons. D'Ambrosio et al. have estimated that $25-33 \%$ of all retinoids absorbed by the intestine are delivered by chylomicrons or chylomicron remnants to tissues other than the liver (white adipose tissue, skeletal muscle, heart, lungs, and kidneys), explaining the good health of humans and mice that lack RBP [76].

In tissues, retinol can be metabolized to retinal (catalyzed by alcohol dehydrogenase) and then to retinoic acid (RA, catalyzed by retinaldehyde dehydrogenase, ALDH1A (also termed RALDH)), an end-stage metabolite. While alcohol dehydrogenase is produced ubiquitously, ALDH1A is selectively expressed, prominently found among dendritic cells in the gastrointestinal tract and among epithelial cells surrounding the airways [77].

Vitamin A deficiencies (VAD) are common in the developed and developing world, although conditions may go unnoticed and underreported in some countries [78]. In Memphis, TN, USA, a significant fraction of children and adults are VAD or vitamin A insufficient [79].

Similar to other ligands for nuclear receptors, vitamin A exhibits a plethora of functions. Virtually every organ system depends upon vitamin $\mathrm{A}$, and this vitamin has a prominent role in immune protection against infectious diseases. The integrity of epithelial cells that line airways, necessary as a first line of defense against respiratory pathogens, is supported by vitamin A.

In vitamin A-deficient (VAD) mice, we observed poor local IgA responses toward respiratory virus vaccines and poor $\mathrm{T}$ cell responses. [80,81]. In VAD mice, both T cells and dendritic cells expressed unusually high levels of $\mathrm{CD} 103$ (the $\alpha \mathrm{E}$ component of $\alpha \mathrm{E} \beta 7$, the receptor for e-cadherin), likely contributing to aberrant immune cell trafficking [82,83]. The immune response was further weakened when the mice were rendered double-deficient for vitamins A and D [84]. VAD is also associated with reduced protection against bacterial infections [85-88] and in a murine B cell acute lymphoblastoid leukemia model (B-ALL), VAD mice exhibited poor tumor clearance compared to 
vitamin-replete controls [89]. In the context of diet-induced obese (DIO) mice, vitamin A levels were normal or above-normal in the blood, but were low in tissues. DIO mice accordingly exhibited poor immune responses toward an influenza virus vaccine and poor control of a subsequent challenge with influenza virus [90].

Vitamin A was correlated with IgG4 and IgA among Memphians and low levels of vitamin A were associated with poor outcomes among children hospitalized with respiratory syncytial virus (RSV) or human metapneumovirus (hMPV) infections [72,91].

\section{Thyroid Hormones and the Immune Response}

The thyroid hormones 3,3',5,5' tetraiodo-L-thyroxine (T4) and 3,3',5,5' triiodo-L-thyroxine (T3), like sex hormones and vitamins, may affect multiple mammalian systems and processes including pregnancy and hypersensitivity $[92,93]$. With regard to the immune response, both innate and adaptive effectors are influenced by thyroid hormones. Cellular concentrations of $\mathrm{T} 3$ and $\mathrm{T} 4$ are regulated by 1,2 and 3 iodothyronine deiodinases (D1, D2, and D3). T3 binds TRs including TR $\alpha 1, T R \beta 1$, TR $\beta 2$, and TR $\beta 3$ to influence gene expression in the nucleus, but similar to other nuclear receptors and ligands, extranuclear signals are also at play. As an example, T4 binds the integrin $\alpha \mathrm{v} \beta 3$ to activate kinase activities ( $5^{\prime}$ adenosine monophosphate-activated protein kinase (AMPK), phosphotidylinositol 3-kinase/Akt (PI3-K/Akt), and mitogen-activated protein kinase (MAPK)) in innate immune cells. T3 supports natural killer (NK) cell activation and the production of interferon $\gamma(\operatorname{IFN} \gamma)$, and a positive correlation has been demonstrated between serum T3 concentrations and NK cell activity in healthy, elderly humans. T3 can additionally support dendritic cell viability, cell maturation, CCR7 expression, cell migration to lymph nodes, and antigen presentation [94]. The relationships between thyroid hormones and immune responses are circular in that abnormal thyroid hormone production will dysregulate the immune response while a dysregulated immune response can attack the thyroid gland to render hormone production abnormal [95].

\section{Nuclear Receptor Cross Regulation Influences the Immune Response}

Of note, male:female differences in immune patterns are not absolute, but are dependent on genetic and microenvironmental factors including vitamin A. We previously showed that when mice were rendered vitamin A deficient (VAD), isotype profiles changed. For male mice, VAD improved the otherwise low levels of serum IgG2b [48]. In addition, we found that when males were VAD, they lost their advantage over females in terms of protection from a bacterial challenge. This result is shown in Figure 1. Whereas the bacterial burden trended lower in control C57BL/6 males compared to females, the burden was significantly higher in VAD males compared to VAD females. This presumed cross-regulation among nuclear receptors is predicted, given that, as described above, nuclear receptors can share ligands, co-receptors and DNA binding locations. Previous examples of receptor cross-regulation include interactions between ER $\alpha$ and PPAR [96], and ER $\alpha$ and RAR [97]. 


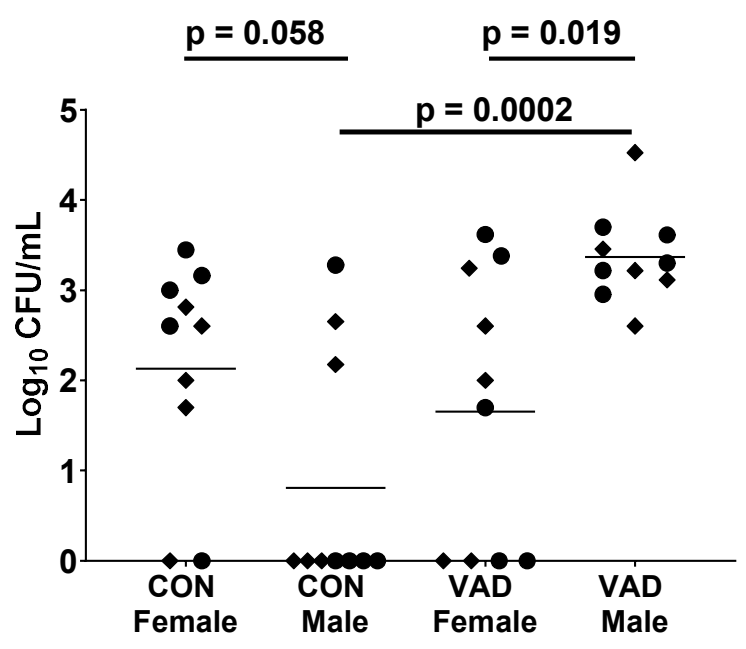

Figure 1. Vitamin A deficient (VAD) male mice exhibit higher bacteria burdens than control males and VAD females. To produce VAD mice, pregnant C57BL/6 (H2-b) mice were purchased from Jackson Laboratories (Bar harbor, ME). Mice were placed on either a control or a VAD diet upon their arrival in the animal facility at St. Jude (days 4-5 gestation). VAD (cat. no. 5WA2, Test Diets) and control (cat. no. 5W9M) diets differed only in vitamin A content, containing either 0 or 15 international units (IU)/g vitamin A palmitate, respectively. Upon reaching adulthood, C57BL/6 control (CON) and VAD mice were lightly anesthetized with isoflurane and intranasally infected with $0.5-1 \times 10^{5}$ CFU of Streptococcus pneumoniae, strain A66.1 (as described previously [86,98,99]). Lung bacterial titers were determined $24 \mathrm{~h}$ post-infection, assigned the value ' 1 ' if below detection. Each dot represents an individual mouse. Results from two experiments are shown, respectively, indicated by circles and diamonds. Significant differences between the paired groups were determined by Mann-Whitney U tests.

\section{Nuclear Receptors, Ligands, and Important Gene Targets among B Cells}

It was originally assumed that B cells were only indirect targets of nuclear receptors and their ligands. Direct targets included antigen-presenting cells such as dendritic cells or macrophages [83]. As examples, Mora et al. showed that vitamin A supported the trafficking of dendritic cells to mucosal sites [83] and Hughes et al. showed that progesterone regulated IFN $\alpha$ in dendritic cells [100-103]. It was then noted that estrogen and progesterone could act directly on B cells by up-regulating AID [102,104,105].

In search of additional, direct influences of nuclear receptors on immunoglobulin expression, we queried the immunoglobulin heavy chain locus for nuclear receptor response elements. We then discovered hotspots for nuclear receptor type I and type II response elements (estrogen response elements (ERE) and retinoic acid response elements (RARE)) in switch sites for $C \mu, C \varepsilon$, and $C \alpha(S \mu$, $\mathrm{S} \varepsilon$, and $\mathrm{S} \alpha)[7,106]$. Using CRISPR/Cas9 technologies, we found that the removal of a single estrogen response element (ERE) from $E \mu$ or the $3^{\prime} R R$ hs1,2 site in a B cell line reduced the CSR from IgM to $\operatorname{IgA}[107]$.

We further observed a partnership of ER $\alpha$ and RNA Pol II [48,107-109], a critical component of CSR. When supplemental estrogen was added to purified B cell cultures, sterile transcript levels improved and there were changes in the positions of ER $\alpha$ and RNA Pol II binding within the immunoglobulin heavy chain locus. For both proteins, there was a focus of binding on the ERE hotspot within $S \mu$. The results suggested that estrogen-liganded ER $\alpha$ served as a chaperone to direct the positioning of RNA Pol II during B cell activation and CSR. These results helped explain, at least in part, the mechanism by which estrogen influenced immunoglobulin expression [109].

A snapshot of these ER $\alpha$ and RNA Pol II binding features is illustrated in Figure 2A. This figure was produced using Integrative Genomics Viewer (IGV) software to show ER $\alpha$ (top two rows) and RNA pol II (third row) binding patterns in areas of $S \mu, C \mu(\operatorname{IgM})$ and $C \delta(\operatorname{IgD})$ regions when B cells were stimulated with lipopolysaccharide (LPS) alone (top row) or LPS plus supplementary estrogen 
(100 nM estrogen, second and third rows). The splenic B cells were purified (by negative selection with antibodies specific for CD43 and CD11b) from C57BL/6 mouse spleens and stimulated in tissue culture overnight before harvest. The red dashes identify the positions of various sequences in forward and reverse (REV) orientations. Figure 2A illustrates the previously described findings that for B cells stimulated in the presence of supplemental estrogen, there was a focused binding of factors on $S \mu$ and also on adenosine-cytidine (AC) repeats in the immunoglobulin heavy chain locus [107-109].

Here, we extend our study by focusing on $E R \alpha$ binding shifts in areas near variable gene segments within immunoglobulin heavy- and light-chain loci. In Figure 2B is shown the kappa variable gene segment, IgKV9-129. When supplementary estrogen was added to B cell cultures, ER $\alpha$ binding was more pronounced near the AC repeat downstream of $\operatorname{IgKV}_{K}$ 9-129. Similar patterns were observed for subsets of $\mathrm{V}_{\mathrm{H}}, \mathrm{V} \lambda$ and Vkgenes, in that they were often flanked either upstream and/or downstream by $A C$ repeats and $E R \alpha$ binding was focused on these sites when supplemental estrogen was added to $B$ cell cultures. We consider that shifts in ER $\alpha$ binding patterns might influence non-identical $V$ gene segment transcription rates [110] (Figure 2B).

Shifts in ER $\alpha$ binding to AC repeats in the context of supplemental estrogen were also noted near non-immunoglobulin genes such as $I L-6$ (Figure 2C). $I L-6$ is known to upregulate following the LPS stimulation of murine B cells, a feature associated with autoimmunity [111,112]. Further experimentation is needed to determine if/how these estrogen-induced shifts of ER $\alpha$ toward the binding of AC-rich regions may alter DNA looping, gene rearrangements, transcription, and/or splicing $[110,113-116]$ to influence gene expression patterns in developing or activated B cells.

\section{A $\quad \lg M / \lg D$}

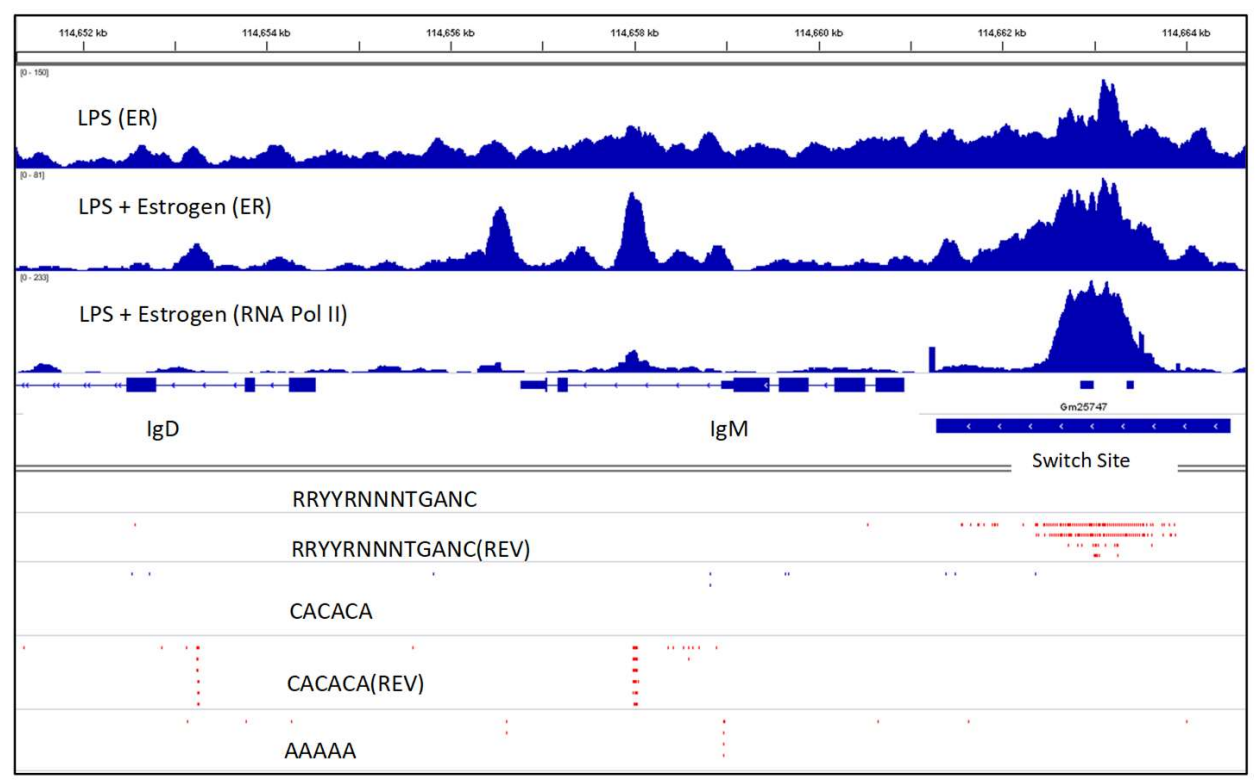

Figure 2. Cont. 
B

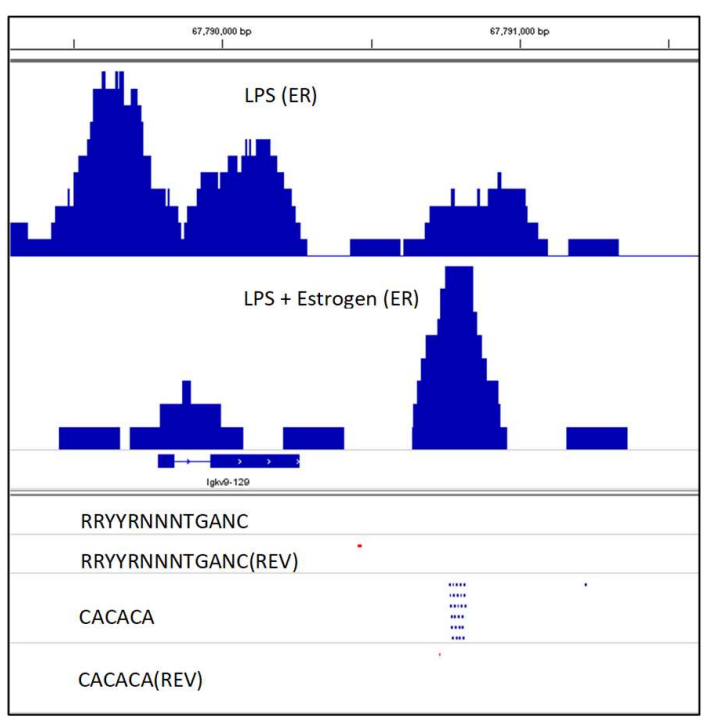

C IL-6

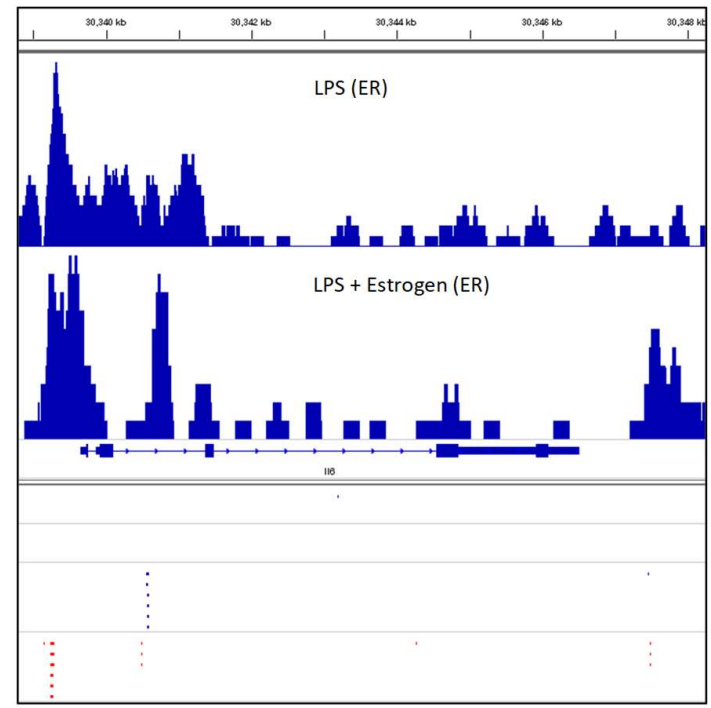

Figure 2. Purified murine B cells were stimulated for 1 day with lipopolysaccharide (LPS) or LPS + supplemental estrogen, followed by chromatin immunoprecipitation studies with antibodies toward ER $\alpha$ (termed ER in this figure) or RNA Pol II, as described previously [48,107-109,117]. Briefly, splenic B cells were isolated from adult, C57BL/6 female mouse spleens, by negative selection with anti-CD43 and anti-CD11b antibodies. The cells were then stimulated overnight with LPS with or without supplemental estrogen $(100 \mathrm{nM})$. Immunoprecipitations were with anti-ER $\alpha$ or anti-RNA Pol II antibodies. Integrative Genomics Viewer (IGV) software was used to generate the figures and to identify motifs in forward and reverse (REV) orientations. (A) The switch site $(\mathrm{S} \mu), \mathrm{C} \mu$ and a portion of the $C \delta$ gene fragment are shown from right to left. Potential ER binding sites are shown using the motif RRYYRNNNTGANC (IGV 'Find motif' function). The positions of adenosine-cytidine (AC)-repeats (CACACA) and poly A (AAAAA) are shown. (B) The Ig kappa V9-129 gene fragment is shown with motifs listed. (C) The IL-6 gene is shown, with the same motifs listed as in (B). The detailed methods and results from chromatin immunoprecipitation studies have been described previously [48,106-109,117].

\section{When B Cells Need Correction}

Two extremes of B cell malfunction include (i) an insufficient immune response against pathogens, and (ii) an over-exuberant immune response toward inert antigens or self. In the first case, the host is vulnerable to numerous viral, bacterial, and fungal infections, whereas in the second case, the host suffers from unnecessary immunopathologies. In cases of influenza virus infections and the more recent SARS-CoV-2 infections, both outcomes have been observed, wherein the immune system may clear the virus too slowly, but following virus clearance, immune responses toward damaged tissues and residual viral antigens may exacerbate disease.

Can clinical corrections be made with a focus on nuclear receptors and their ligands? In the case of VAD, vitamin supplementation may provide a simple form of correction and in the case of sex hormones, the use of agonists/antagonists (e.g., estrogen/tamoxifen) may be used. As described above, in VAD mice, we observed poor IgA responses toward respiratory virus vaccines. These could be corrected if vitamin supplements were administered at the time of vaccination [80,81]. In the mouse model of diet-induced obesity, vitamin A supplements supported antibody production and assisted clearance of virus at a later stage when vaccinated obese mice were challenged [90]. The reductions observed among the virus-specific immune responses in mice that were double deficient for vitamins A and D could also be corrected [84]. Again, we found that vitamin supplements, in this case with vitamins $A$ and $D$, could be administered at the time of vaccination to correct the antibody response toward vaccines [84]. 
However, despite the apparent simplicity of supplementation methods, caution is advised in the clinical arena. Outcomes of clinical supplementation studies have been highly variable, dependent on the geographical location, diet, sex, and age of study participants. For example, studies have often shown that vitamin A supplements provide benefit in the developing world, but different outcomes for males and females have been noted [118-120] with males sometimes exhibiting greater benefit from supplementation compared to females.

The timing of supplementation relative to vaccination or infection also affects outcome. Hussey et al. described a randomized, double-blind clinical study in which children hospitalized with measles were administered either a total oral dose of 400,000 international units (IU) retinyl palmitate or a placebo control [121]. The authors found that the children who received the vitamin recovered more rapidly from pneumonia and diarrhea compared to the controls and experienced shorter hospital stays [120-122]. In contrast, Bresee et al. demonstrated that vitamin A supplements worsened the outcome when given to children hospitalized with respiratory syncytial virus (RSV) infections in the United States [123]. Our own study of influenza virus vaccinations in 2-8 year old children in Memphis, TN, showed that baseline vitamin A levels correlated positively with the vaccine-induced immune response whereas baseline vitamin $\mathrm{D}$ levels correlated negatively. When vitamin $\mathrm{A}+\mathrm{D}$ supplements were administered to these children at the time of vaccination, there were improved responses compared to placebo controls, but only when children had low vitamin A and D levels at baseline. The responses were worsened by vitamin A + D supplementation when the children were vitamin replete at baseline [79]. In a separate study in Indonesia, six month-old infants received a vitamin A supplement at the time of measles vaccination; at twelve months the supplemented children had a lower sero-conversion rate toward the vaccine compared to the controls [124-126]. This result contrasted with that of a study of nine month-old children given vitamin A supplements at the time of a single measles vaccine dose in Guinea Bissau. Then, the geometric mean titers toward the vaccine were significantly improved in the supplemented compared to the control children at 18 months, particularly for boys $[125,127]$.

Like vitamin supplements, thyroid and sex hormone supplements have yielded variable results in the clinic. When T3 was administered to elderly participants to increase NK activity, improvements were only indicated when baseline T3 concentrations were low [128]. The selective estrogen receptor modulator (SERM) tamoxifen exhibited both supportive and inhibitory functions, depending on the tissue target [129] and the benefit of estrogen replacement therapy in post-menopausal women to improve vaccine and virus-specific immune responses has been a topic of continued debate [130-135].

The results described above demonstrate that supplementation cannot be implemented globally using a one-size-fits-all strategy. Rather, the fine-tuning of supplementation programs based on population genetics and microenvironments may be required to yield predictable and beneficial outcomes.

Today, new technologies offer new treatment options. There are now a variety of methods for blocking protein interactions with DNA or RNA (e.g., CRISPR-CAS9 technologies, anti-sense oligonucleotides, DNA decoys or small inhibitory molecules [113,116,136-149]). Perhaps fine-tuned and targeted manipulations of nuclear receptor binding sites within promoters, enhancers and switch sites of the immunoglobulin loci will ultimately prove successful for the control and optimization of immunoglobulin expression.

Funding: This study was supported in part by NIH NCI P30CA21765, NIH NIAID Collaborative Influenza Vaccine Innovation Centers (CIVICs) contract 75N93019C00052, and ALSAC. The content is solely the responsibility of the authors and does not necessarily represent the official views of the National Institutes of Health.

Conflicts of Interest: The authors declare no conflict of interest. 


\section{Abbreviations}

$\begin{array}{ll}1,25(\mathrm{OH}) 2 \mathrm{D} & \text { 1,25-dihydroxy vitamin D } \\ \text { 25(OH)D } & \text { 25-hydroxy vitamin D } \\ \text { VAD } & \text { Vitamin A deficient } \\ \text { ER } & \text { Estrogen receptor } \\ \text { ChIP } & \text { Chromatin immunoprecipitation } \\ \text { DIO } & \text { Diet induced obesity } \\ \text { RAR } & \text { Retinoic acid receptor } \\ \text { PPAR } & \text { Peroxisome proliferator activated receptor } \\ \text { RXR } & \text { Retinoid } X \text { receptor }\end{array}$

\section{References}

1. Evans, R.M.; Mangelsdorf, D.J. Nuclear receptors, RXR, and the big bang. Cell 2014, 157, 255-266. [CrossRef]

2. Rastinejad, F.; Huang, P.; Chandra, V.; Khorasanizadeh, S. Understanding nuclear receptor form and function using structural biology. J. Mol. Endocrinol. 2013, 51, T1-T21. [CrossRef]

3. Dawson, M.I.; Xia, Z. The retinoid X receptors and their ligands. Biochim. Biophys. Acta 2011, 1821, 21-56. [CrossRef] [PubMed]

4. Shaw, N.; Elholm, M.; Noy, N. Retinoic acid is a high affinity selective ligand for the peroxisome proliferator-activated receptor beta/delta. J. Biol. Chem. 2003, 278, 41589-41592. [CrossRef]

5. Napoli, J.L. Functions of intracellular retinoid binding-proteins. Subcell. Biochem. 2016, 81, 21-76. [CrossRef] [PubMed]

6. Mangelsdorf, D.J.; Thummel, C.; Beato, M.; Herrlich, P.; Schutz, G.; Umesono, K.; Blumberg, B.; Kastner, P.; Mark, M.; Chambon, P.; et al. The nuclear receptor superfamily: The second decade. Cell 1995, 83, 835-839. [CrossRef]

7. Klinge, C.M. Estrogen receptor interaction with estrogen response elements. Nucleic Acids Res. 2001, 29, 2905-2919. [CrossRef] [PubMed]

8. Stunnenberg, H.G. Mechanisms of transactivation by retinoic acid receptors. BioEssays News Rev. Mol. Cell. Dev. Biol. 1993, 15, 309-315. [CrossRef]

9. Mader, S.; Leroy, P.; Chen, J.Y.; Chambon, P. Multiple parameters control the selectivity of nuclear receptors for their response elements. Selectivity and promiscuity in response element recognition by retinoic acid receptors and retinoid $X$ receptors. J. Biol. Chem. 1993, 268, 591-600.

10. Zheng, W.; Lu, Y.; Tian, S.; Ma, F.; Wei, Y.; Xu, S.; Li, Y. Structural insights into the heterodimeric complex of the nuclear receptors FXR and RXR. J. Biol. Chem. 2018, 293, 12535-12541. [CrossRef] [PubMed]

11. Aranda, A.; Pascual, A. Nuclear hormone receptors and gene expression. Physiol. Rev. 2001, 81, 1269-1304. [CrossRef] [PubMed]

12. Steineger, H.H.; Arntsen, B.M.; Spydevold, O.; Sorensen, H.N. Retinoid X receptor (RXR alpha) gene expression is regulated by fatty acids and dexamethasone in hepatic cells. Biochimie 1997, 79, 107-110. [CrossRef]

13. Bastien, J.; Rochette-Egly, C. Nuclear retinoid receptors and the transcription of retinoid-target genes. Gene 2004, 328, 1-16. [CrossRef]

14. De Bruyn, R.; Bollen, R.; Claessens, F. Identification and characterization of androgen response elements. Methods Mol. Biol. 2011, 776, 81-93. [CrossRef] [PubMed]

15. Wilson, S.; Qi, J.; Filipp, F.V. Refinement of the androgen response element based on ChIP-Seq in androgen-insensitive and androgen-responsive prostate cancer cell lines. Sci. Rep. 2016, 6, 32611. [CrossRef]

16. Lee, M.O.; Liu, Y.; Zhang, X.K. A retinoic acid response element that overlaps an estrogen response element mediates multihormonal sensitivity in transcriptional activation of the lactoferrin gene. Mol. Cell. Biol. 1995, 15, 4194-4207. [CrossRef]

17. Krasowski, M.D.; Ni, A.; Hagey, L.R.; Ekins, S. Evolution of promiscuous nuclear hormone receptors: LXR, FXR, VDR, PXR, and CAR. Mol. Cell. Endocrinol. 2011, 334, 39-48. [CrossRef]

18. Carlberg, C. Mechanisms of nuclear signalling by vitamin D3. Interplay with retinoid and thyroid hormone signalling. Eur. J. Biochem. 1995, 231, 517-527. [CrossRef] 
19. Blumenberg, M.; Connolly, D.M.; Freedberg, I.M. Regulation of keratin gene expression: The role of the nuclear receptors for retinoic acid, thyroid hormone, and vitamin D3. J. Investig. Dermatol. 1992, 98, S42-S49. [CrossRef]

20. Kliewer, S.A.; Umesono, K.; Mangelsdorf, D.J.; Evans, R.M. Retinoid X receptor interacts with nuclear receptors in retinoic acid, thyroid hormone and vitamin D3 signalling. Nature 1992, 355, 446-449. [CrossRef]

21. Green, S. Promiscuous liaisons. Nature 1993, 361, 590-591. [CrossRef] [PubMed]

22. Koszewski, N.J.; Herberth, J.; Malluche, H.H. Retinoic acid receptor gamma 2 interactions with vitamin D response elements. J. Steroid Biochem. Mol. Biol. 2010, 120, 200-207. [CrossRef]

23. Zimber, A.; Chedeville, A.; Abita, J.P.; Barbu, V.; Gespach, C. Functional interactions between bile acids, all-trans retinoic acid, and 1,25-dihydroxy-vitamin D3 on monocytic differentiation and myeloblastin gene down-regulation in HL60 and THP-1 human leukemia cells. Cancer Res. 2000, 60, 672-678. [PubMed]

24. Thompson, P.D.; Jurutka, P.; Haussler, C.A.; Whitfield, G.K.; Haussler, M.R. Heterodimeric DNA binding by the vitamin $\mathrm{D}$ receptor and retinoid $\mathrm{X}$ receptors is enhanced by 1,25-dihydroxyvitamin D3 and inhibited by 9-cis-retinoic acid. Evidence for allosteric receptor interactions. J. Biol. Chem. 1998, 273, 8483-8491. [CrossRef]

25. Botling, J.; Öberg, F.; Törmä, H.; Tuohimaa, P.; Bläuer, M.; Nilsson, K. Vitamin D3- and retinoic acid-induced monocytic differentiation: Interactions between the endogenous vitamin D3 receptor, retinoic acid receptors, and retinoid X receptors in U-937 cells. Cell Growth Differ. 1996, 7, 1239-1249.

26. Ross-Innes, C.S.; Stark, R.; Holmes, K.A.; Schmidt, M.; Spyrou, C.; Russell, R.; Massie, C.E.; Vowler, S.L.; Eldridge, M.; Carroll, J.S. Cooperative interaction between retinoic acid receptor-alpha and estrogen receptor in breast cancer. Genes Dev. 2010, 24, 171-182. [CrossRef] [PubMed]

27. Vasudevan, N.; Davidkova, G.; Zhu, Y.-S.; Koibuchi, N.; Chin, W.W.; Pfaff, D. Differential interaction of estrogen receptor and thyroid hormone receptor isoforms on the rat oxytocin receptor promoter leads to differences in transcriptional regulation. Neuroendocrinology 2001, 74, 309-324. [CrossRef] [PubMed]

28. Zhu, Y.S.; Yen, P.M.; Chin, W.W.; Pfaff, D.W. Estrogen and thyroid hormone interaction on regulation of gene expression. Proc. Natl. Acad. Sci. USA 1996, 93, 12587-12592. [CrossRef]

29. Mader, S.; Chen, J.Y.; Chen, Z.; White, J.; Chambon, P.; Gronemeyer, H. The patterns of binding of RAR, RXR and TR homo- and heterodimers to direct repeats are dictated by the binding specificites of the DNA binding domains. EMBO J. 1993, 12, 5029-5041. [CrossRef] [PubMed]

30. Deschênes, J.; Bourdeau, V.; White, J.H.; Mader, S. Regulation of GREB1 transcription by estrogen receptor alpha through a multipartite enhancer spread over $20 \mathrm{~kb}$ of upstream flanking sequences. J. Biol. Chem. 2007, 282, 17335-17339. [CrossRef]

31. Sun, J.; Nawaz, Z.; Slingerland, J.M. Long-range activation of GREB1 by estrogen receptor via three distal consensus estrogen-responsive elements in breast cancer cells. Mol. Endocrinol. 2007, 21, 2651-2662. [CrossRef] [PubMed]

32. Osmond, D.G.; Rolink, A.; Melchers, F. Murine B lymphopoiesis: Towards a unified model. Immunol. Today 1998, 19, 65-68. [CrossRef]

33. Dai, Y.-C.; Zhong, J.; Xu, J.-F. Regulatory B cells in infectious disease (Review). Mol. Med. Rep. 2017, 16, 3-10. [CrossRef] [PubMed]

34. Stavnezer, J.; Schrader, C.E. IgH chain class switch recombination: Mechanism and regulation. J. Immunol. 2014, 193, 5370-5378. [CrossRef] [PubMed]

35. Zaller, D.M.; Eckhardt, L.A. Deletion of a B-cell-specific enhancer affects transfected, but not endogenous, immunoglobulin heavy-chain gene expression. Proc. Natl. Acad. Sci. USA 1985, 82, 5088-5092. [CrossRef] [PubMed]

36. Su, L.K.; Kadesch, T. The immunoglobulin heavy-chain enhancer functions as the promoter for I mu sterile transcription. Mol. Cell. Biol. 1990, 10, 2619-2624. [CrossRef]

37. Birshtein, B.K. Epigenetic regulation of individual modules of the immunoglobulin heavy chain locus $3^{\prime}$ regulatory region. Front. Immunol. 2014, 5, 163. [CrossRef]

38. Chatterjee, S.; Ju, Z.; Hassan, R.; Volpi, S.A.; Emelyanov, A.V.; Birshtein, B.K. Dynamic Changes in Binding of immunoglobulin heavy chain $3^{\prime}$ regulatory region to protein factors during class switching. J. Biol. Chem. 2011, 286, 29303-29312. [CrossRef] 
39. Frezza, D.; Tolusso, B.; Giambra, V.; Gremese, E.; Marchini, M.; Nowik, M.; Serone, E.; D'Addabbo, P.; Mattioli, C.; Canestri, S.; et al. Polymorphisms of the IgH enhancer HS1.2 and risk of systemic lupus erythematosus. Ann. Rheum. Dis. 2012, 71, 1309-1315. [CrossRef] [PubMed]

40. Muenchhoff, M.; Goulder, P.J. Sex differences in pediatric infectious diseases. J. Infect. Dis. 2014, 209 (Suppl. 3), S120-S126. [CrossRef]

41. Borchers, A.T.; Chang, C.; Gershwin, M.E.; Gershwin, L.J. Respiratory syncytial virus—A comprehensive review. Clin. Rev. Allergy Immunol. 2013, 45, 331-379. [CrossRef] [PubMed]

42. Klein, S.L. Sex influences immune responses to viruses, and efficacy of prophylaxis and treatments for viral diseases. BioEssays News Rev. Mol. Cell. Dev. Biol. 2012, 34, 1050-1059. [CrossRef]

43. Green, M.S. The male predominance in the incidence of infectious diseases in children: A postulated explanation for disparities in the literature. Int. J. Epidemiol. 1992, 21, 381-386. [CrossRef] [PubMed]

44. Garenne, M. Sex differences in measles mortality: A world review. Int. J. Epidemiol. 1994, 23, $632-642$. [CrossRef]

45. Segal, A.O.; Crighton, E.J.; Moineddin, R.; Mamdani, M.; Upshur, R.E. Croup hospitalizations in Ontario: A 14-year time-series analysis. Pediatrics 2005, 116, 51-55. [CrossRef]

46. Fischinger, S.; Boudreau, C.M.; Butler, A.L.; Streeck, H.; Alter, G. Sex differences in vaccine-induced humoral immunity. Semin. Immunopathol. 2019, 41, 239-249. [CrossRef] [PubMed]

47. Sue, K. The science behind "man flu". BMJ 2017, 359, j5560. [CrossRef]

48. Jones, B.G.; E Sealy, R.; Penkert, R.R.; Surman, S.; Maul, R.W.; Neale, G.; Xu, B.; Gearhart, P.J.; Hurwitz, J.L. Complex sex-biased antibody responses: Estrogen receptors bind estrogen response elements centered within immunoglobulin heavy chain gene enhancers. Int. Immunol. 2018, 31, 141-156. [CrossRef]

49. Fish, E.N. The X-files in immunity: Sex-based differences predispose immune responses. Nat. Rev. Immunol. 2008, 8, 737-744. [CrossRef]

50. Engelmann, F.; Rivera, A.; Park, B.; Messerle-Forbes, M.; Jensen, J.T.; Messaoudi, I. Impact of estrogen therapy on lymphocyte homeostasis and the response to seasonal influenza vaccine in post-menopausal women. PLoS ONE 2016, 11, e0149045. [CrossRef]

51. Cai, H. Sex difference and smoking predisposition in patients with COVID-19. Lancet Respir. Med. 2020, 8, e20. [CrossRef]

52. Gebhard, C.; Regitz-Zagrosek, V.; Neuhauser, H.K.; Morgan, R.; Klein, S.L. Impact of sex and gender on COVID-19 outcomes in Europe. Biol. Sex Differ. 2020, 11, 29. [CrossRef] [PubMed]

53. Weckerle, C.E.; Niewold, T.B. The unexplained female predominance of systemic lupus erythematosus: Clues from genetic and cytokine studies. Clin. Rev. Allergy Immunol. 2011, 40, 42-49. [CrossRef] [PubMed]

54. Handelsman, D.J.; Newman, J.D.; Jimenez, M.; McLachlan, R.; Sartorius, G.; Jones, G.R. Performance of direct estradiol immunoassays with human male serum samples. Clin. Chem. 2014, 60, 510-517. [CrossRef] [PubMed]

55. James, D.; Steer, P.; Weiner, C.; Gonik, B.; Crowther, C.; Robson, S.; Ramsay, M. Pregnancy and laboratory studies: A reference table for clinicians. Obstet. Gynecol. 2010, 115, 868. [CrossRef] [PubMed]

56. Keselman, A.; Heller, N. Estrogen signaling modulates allergic inflammation and contributes to sex differences in asthma. Front. Immunol. 2015, 6, 568. [CrossRef]

57. Shim, G.J.; Kis, L.L.; Warner, M.; Gustafsson, J.A. Autoimmune glomerulonephritis with spontaneous formation of splenic germinal centers in mice lacking the estrogen receptor alpha gene. Proc. Natl. Acad. Sci. USA 2004, 101, 1720-1724. [CrossRef]

58. Svenson, J.L.; Eudaly, J.; Ruiz, P.; Korach, K.S.; Gilkeson, G.S. Impact of estrogen receptor deficiency on disease expression in the NZM2410 lupus prone mouse. Clin. Immunol. 2008, 128, 259-268. [CrossRef]

59. Verthelyi, D.; Ansar Ahmed, S. Characterization of estrogen-induced autoantibodies to cardiolipin in non-autoimmune mice. J. Autoimmun. 1997, 10, 115-125. [CrossRef]

60. Ahmed, S.A.; Verthelyi, D. Antibodies to cardiolipin in normal C57BL/6J mice: Induction by estrogen but not dihydrotestosterone. J. Autoimmun. 1993, 6, 265-279. [CrossRef]

61. Charles, L.M.; Nicol, T. Effect of diethylstilboestrol on the serum gamma-globulin in the guinea pig. Nature 1961, 192, 565-566. [CrossRef] [PubMed]

62. Kenny, J.F.; Pangburn, P.C.; Trail, G. Effect of estradiol on immune competence: In vivo and in vitro studies. Infect. Immun. 1976, 13, 448-456. [CrossRef] [PubMed] 
63. Han, D.; Denison, M.S.; Tachibana, H.; Yamada, K. Effects of Estrogenic compounds on immunoglobulin production by mouse splenocytes. Biol. Pharm. Bull. 2002, 25, 1263-1267. [CrossRef]

64. Kanda, N.; Tamaki, K. Estrogen enhances immunoglobulin production by human PBMCs. J. Allergy Clin. Immunol. 1999, 103, 282-288. [CrossRef]

65. Kanda, N.; Tsuchida, T.; Tamaki, K. Testosterone inhibits immunoglobulin production by human peripheral blood mononuclear cells. Clin. Exp. Immunol. 1996, 106, 410-415. [CrossRef]

66. Babina, M.; Kirn, F.; Hoser, D.; Ernst, D.; Rohde, W.; Zuberbier, T.; Worm, M. Tamoxifen counteracts the allergic immune response and improves allergen-induced dermatitis in mice. Clin. Exp. Allergy 2010, 40, 1256-1265. [CrossRef] [PubMed]

67. Bikle, D.D. Vitamin D: Newer concepts of its metabolism and function at the basic and clinical level. J. Endocr. Soc. 2020, 4, bvz038. [CrossRef] [PubMed]

68. Dovnik, A.; Mujezinović, F. The association of vitamin D levels with common pregnancy complications. Nutrients 2018, 10, 867. [CrossRef]

69. Mui, Y.; Lee, B.Y.; Adam, A.; Kharmats, A.Y.; Budd, N.; Nau, C.; Gittelsohn, J. Healthy versus unhealthy suppliers in food desert neighborhoods: A network analysis of corner stores' food supplier networks. Int. J. Environ. Res. Public Health 2015, 12, 15058-15074. [CrossRef]

70. Chesney, R.W. Vitamin D and the magic mountain: The anti-infectious role of the vitamin. J. Pediatr. 2010, 156, 698-703. [CrossRef]

71. Mirzakhani, H.; Al-Garawi, A.; Weiss, S.T.; Litonjua, A.A. Vitamin D and the development of allergic disease: How important is it? Clin. Exp. Allergy 2015, 45, 114-125. [CrossRef] [PubMed]

72. Jones, B.G.; Oshansky, C.M.; Bajracharya, R.; Tang, L.; Sun, Y.; Wong, S.S.; Webby, R.; Thomas, P.G.; Hurwitz, J.L. Retinol binding protein and vitamin D associations with serum antibody isotypes, serum influenza virus-specific neutralizing activities and airway cytokine profiles. Clin. Exp. Immunol. 2016, 183, 239-247. [CrossRef] [PubMed]

73. Nnoaham, K.E.; Clarke, A. Low serum vitamin D levels and tuberculosis: A systematic review and meta-analysis. Int. J. Epidemiol. 2008, 37, 113-119. [CrossRef] [PubMed]

74. Wayse, V.; Yousafzai, A.; Mogale, K.; Filteau, S. Association of subclinical vitamin D deficiency with severe acute lower respiratory infection in Indian children under 5 y. Eur. J. Clin. Nutr. 2004, 58, 563-567. [CrossRef] [PubMed]

75. Ginde, A.A.; Mansbach, J.M.; Camargo, C.A., Jr. Association between serum 25-hydroxyvitamin D level and upper respiratory tract infection in the third national health and nutrition examination survey. Arch. Intern. Med. 2009, 169, 384-390. [CrossRef]

76. D'Ambrosio, D.N.; Clugston, R.D.; Blaner, W.S. Vitamin A metabolism: An update. Nutrients 2011, 3, 63. [CrossRef]

77. Rudraraju, R.; Jones, B.G.; Surman, S.L.; Sealy, R.E.; Thomas, P.G.; Hurwitz, J.L. Respiratory tract epithelial cells express retinaldehyde dehydrogenase ALDH1A and enhance IgA production by stimulated B cells in the presence of vitamin A. PLoS ONE 2014, 9, e86554. [CrossRef]

78. Stephens, D.; Jackson, P.L.; Gutierrez, Y. Subclinical vitamin A deficiency: A potentially unrecognized problem in the United States. Pediatr. Nurs. 1996, 22, 377-389.

79. Patel, N.; Penkert, R.R.; Jones, B.G.; Sealy, R.E.; Surman, S.L.; Sun, Y.; Tang, L.; DeBeauchamp, J.; Webb, A.; Richardson, J.; et al. Baseline serum vitamin A and D levels determine benefit of oral vitamin A\&D supplements to humoral immune responses following pediatric influenza vaccination. Viruses 2019, 11, 907. [CrossRef]

80. Surman, S.L.; Jones, B.G.; Sealy, R.E.; Rudraraju, R.; Hurwitz, J.L. Oral retinyl palmitate or retinoic acid corrects mucosal IgA responses toward an intranasal influenza virus vaccine in vitamin A deficient mice. Vaccine 2014, 32, 2521-2524. [CrossRef]

81. Surman, S.L.; Jones, B.G.; Rudraraju, R.; Sealy, R.E.; Hurwitz, J.L. Intranasal administration of retinyl palmitate with a respiratory virus vaccine corrects impaired mucosal IgA response in the vitamin A-deficient host. Clin. Vaccine Immunol. 2014, 21, 598-601. [CrossRef]

82. Rudraraju, R.; Surman, S.L.; Jones, B.G.; Sealy, R.; Woodland, D.L.; Hurwitz, J.L. Reduced frequencies and heightened CD103 expression among virus-induced CD8(+) T cells in the respiratory tract airways of vitamin A-deficient mice. Clin. Vaccine Immunol. 2012, 19, 757-765. [CrossRef] [PubMed] 
83. Mora, J.R.; Iwata, M.; Von Andrian, U.H. Vitamin effects on the immune system: Vitamins A and D take centre stage. Nat. Rev. Immunol. 2008, 8, 685-698. [CrossRef] [PubMed]

84. Surman, S.L.; Penkert, R.R.; Jones, B.G.; Sealy, R.E.; Hurwitz, J.L. Vitamin supplementation at the time of immunization with a cold-adapted influenza virus vaccine corrects poor mucosal antibody responses in mice deficient for vitamins A and D. Clin. Vaccine Immunol. 2016, 23, 219-227. [CrossRef] [PubMed]

85. Penkert, R.R.; Hankins, J.S.; Young, N.S.; Hurwitz, J.L. Vaccine design informed by virus-induced immunity. Viral Immunol. 2020, 33, 342-350. [CrossRef]

86. Penkert, R.R.; Iverson, A.; Rosch, J.W.; Hurwitz, J.L. Prevnar-13 vaccine failure in a mouse model for vitamin A deficiency. Vaccine 2017, 35, 6264-6268. [CrossRef]

87. Pasatiempo, A.M.; Bowman, T.A.; Taylor, C.E.; Ross, A.C. Vitamin A depletion and repletion: Effects on antibody response to the capsular polysaccharide of Streptococcus pneumoniae, type III (SSS-III). Am. J. Clin. Nutr. 1989, 49, 501-510. [CrossRef]

88. Ross, A.C. Vitamin A deficiency and retinoid repletion regulate the antibody response to bacterial antigens and the maintenance of natural killer cells. Clin. Immunol. Immunopathol. 1996, 80, S63-S72. [CrossRef]

89. Annu, K.; Cline, C.; Yasuda, K.; Ganguly, S.; Pesch, A.; Cooper, B.; Janke, L.; Payton, M.; Mukherjee, K.; Surman, S.L.; et al. Role of vitamins A and D in BCR-ABL Arf(-/-) acute lymphoblastic leukemia. Sci. Rep. 2020, 10, 2359. [CrossRef]

90. Penkert, R.R.; Cortez, V.; Karlsson, E.; Livingston, B.; Surman, S.L.; Li, Y.; Ross, A.C.; Schultz-Cherry, S.; Hurwitz, J.L. Vitamin A corrects tissue deficits in diet-induced obese mice and reduces influenza infection after vaccination and challenge. Obesity (Silver Spring) 2020, in press.

91. Hurwitz, J.L.; Jones, B.G.; Penkert, R.R.; Gansebom, S.; Sun, Y.; Tang, L.; Bramley, A.M.; Jain, S.; McCullers, J.A.; Arnold, S.R. Low retinol-binding protein and vitamin D levels are associated with severe outcomes in children hospitalized with lower respiratory tract infection and respiratory syncytial virus or human metapneumovirus detection. J. Pediatr. 2017, 187, 323-327. [CrossRef] [PubMed]

92. Forehan, S. Thyroid disease in the perinatal period. Aust. Fam. Physician 2012, 41, 578-581. [PubMed]

93. Shibata, H.; Hayakawa, H.; Hirukawa, M.; Tadokoro, K.; Ogata, E. Hypersensitivity caused by synthetic thyroid hormones in a hypothyroid patient with Hashimoto's thyroiditis. Arch. Intern. Med. 1986, 146, 1624-1625. [CrossRef] [PubMed]

94. Montesinos, M.D.M.; Pellizas, C.G. Thyroid hormone action on innate immunity. Front. Endocrinol. (Lausanne) 2019, 10, 350. [CrossRef] [PubMed]

95. Bliddal, S.; Nielsen, C.H.; Feldt-Rasmussen, U. Recent advances in understanding autoimmune thyroid disease: The tallest tree in the forest of polyautoimmunity. F1000Research 2017, 6, 1776. [CrossRef]

96. Keller, H.; Givel, F.; Perroud, M.; Wahli, W. Signaling cross-talk between peroxisome proliferator-activated receptor/retinoid $\mathrm{X}$ receptor and estrogen receptor through estrogen response elements. Mol. Endocrinol. 1995, 9, 794-804. [CrossRef]

97. Lee, S.-K.; Choi, H.-S.; Song, M.-R.; Lee, M.-O.; Lee, J.W. Estrogen receptor, a common interaction partner for a subset of nuclear receptors. Mol. Endocrinol. 1998, 12, 1184-1192. [CrossRef]

98. Smith, A.M.; Smith, A.P. A critical, nonlinear threshold dictates bacterial invasion and initial kinetics during influenza. Sci. Rep. 2016, 6, 38703. [CrossRef]

99. Penkert, R.R.; Rowe, H.M.; Surman, S.L.; Sealy, R.E.; Rosch, J.; Hurwitz, J.L. Influences of vitamin A on vaccine immunogenicity and efficacy. Front. Immunol. 2019, 10, 1576. [CrossRef]

100. Hughes, G.C.; Martín, D.; Zhang, K.; Hudkins, K.L.; Alpers, C.E.; Clark, E.A.; Elkon, K.B. Decrease in glomerulonephritis and Th1-associated autoantibody production after progesterone treatment in NZB/NZW mice. Arthritis Rheum. 2009, 60, 1775-1784. [CrossRef]

101. Hughes, G.C.; Thomas, S.; Li, C.; Kaja, M.-K.; Clark, E.A. Cutting edge: Progesterone regulates IFN-alpha production by plasmacytoid dendritic cells. J. Immunol. 2008, 180, 2029-2033. [CrossRef] [PubMed]

102. Pauklin, S.; Sernández, I.V.; Bachmann, G.; Ramiro, A.R.; Petersen-Mahrt, S.K. Estrogen directly activates AID transcription and function. J. Exp. Med. 2009, 206, 99-111. [CrossRef] [PubMed]

103. Fear, D.J.; McCloskey, N.; O'Connor, B.; Felsenfeld, G.; Gould, H.J. Transcription of Ig germline genes in single human B cells and the role of cytokines in isotype determination. J. Immunol. 2004, 173, 4529-4538. [CrossRef] [PubMed]

104. Pauklin, S.; Petersen-Mahrt, S.K. Progesterone inhibits activation-induced deaminase by binding to the promoter. J. Immunol. 2009, 183, 1238-1244. [CrossRef] [PubMed] 
105. Maul, R.W.; Gearhart, P.J. Women, autoimmunity, and cancer: A dangerous liaison between estrogen and activation-induced deaminase? J. Exp. Med. 2009, 206, 11-13. [CrossRef]

106. Hurwitz, J.L.; Penkert, R.R.; Xu, B.; Fan, Y.; Partridge, J.F.; Maul, R.W.; Gearhart, P.J. hotspots for vitamin-steroid-thyroid hormone response elements within switch regions of immunoglobulin heavy chain loci predict a direct influence of vitamins and hormones on B cell class switch recombination. Viral Immunol. 2016, 29, 132-136. [CrossRef] [PubMed]

107. Sealy, R.E.; Jones, B.G.; Surman, S.L.; Penkert, R.R.; Pelletier, S.; Neale, G.; Hurwitz, J.L. Will attention by vaccine developers to the host's nuclear hormone levels and immunocompetence improve vaccine success? Vaccines (Basel) 2019, 7, 26. [CrossRef]

108. Jones, B.G.; Penkert, R.R.; Surman, S.L.; Sealy, R.E.; Pelletier, S.; Xu, B.; Neale, G.; Maul, R.W.; Gearhart, P.J.; Hurwitz, J.L. Matters of life and death: How estrogen and estrogen receptor binding to the immunoglobulin heavy chain locus may influence outcomes of infection, allergy, and autoimmune disease. Cell. Immunol. 2019, 346, 103996. [CrossRef] [PubMed]

109. Jones, B.G.; Sealy, R.E.; Penkert, R.R.; Surman, S.L.; Birshtein, B.K.; Xu, B.; Neale, G.; Maul, R.W.; Gearhart, P.J.; Hurwitz, J.L. From influenza virus infections to lupus: Synchronous estrogen receptor alpha and RNA polymerase II binding within the immunoglobulin heavy chain locus. Viral Immunol. 2020, 33, 307-315. [CrossRef]

110. Yancopoulos, G.D.; Alt, F.W. Developmentally controlled and tissue-specific expression of unrearranged VH gene segments. Cell 1985, 40, 271-281. [CrossRef]

111. Barr, T.A.; Shen, P.; Brown, S.; Lampropoulou, V.; Roch, T.; Lawrie, S.; Fan, B.; O'Connor, R.A.; Anderton, S.M.; Bar-Or, A.; et al. B cell depletion therapy ameliorates autoimmune disease through ablation of IL-6-producing B cells. J. Exp. Med. 2012, 209, 1001-1010. [CrossRef] [PubMed]

112. Arkatkar, T.; Du, S.W.; Jacobs, H.M.; Dam, E.M.; Hou, B.; Buckner, J.H.; Rawlings, D.J.; Jackson, S.W. B cell-derived IL-6 initiates spontaneous germinal center formation during systemic autoimmunity. J. Exp. Med. 2017, 214, 3207-3217. [CrossRef] [PubMed]

113. Hua, Y.; Vickers, T.A.; Okunola, H.L.; Bennett, C.F.; Krainer, A.R. Antisense masking of an hnRNP A1/A2 intronic splicing silencer corrects SMN2 splicing in transgenic mice. Am. J. Hum. Genet. 2008, 82, 834-848. [CrossRef] [PubMed]

114. Hui, J.; Hung, L.-H.; Heiner, M.; Schreiner, S.; Neumüller, N.; Reither, G.; Haas, S.A.; Bindereif, A. Intronic CA-repeat and CA-rich elements: A new class of regulators of mammalian alternative splicing. EMBO J. 2005, 24, 1988-1998. [CrossRef]

115. Naftelberg, S.; Schor, I.E.; Ast, G.; Kornblihtt, A.R. Regulation of alternative splicing through coupling with transcription and chromatin structure. Annu. Rev. Biochem. 2015, 84, 165-198. [CrossRef] [PubMed]

116. Singh, N.K.; Singh, N.N.; Androphy, E.J.; Singh, R.N. Splicing of a critical exon of human survival motor neuron is regulated by a unique silencer element located in the last intron. Mol. Cell. Biol. 2006, 26, 1333-1346. [CrossRef]

117. Jones, B.G.; Penkert, R.R.; Xu, B.; Fan, Y.; Neale, G.; Gearhart, P.J.; Hurwitz, J.L. Binding of estrogen receptors to switch sites and regulatory elements in the immunoglobulin heavy chain locus of activated $B$ cells suggests a direct influence of estrogen on antibody expression. Mol. Immunol. 2016, 77, 97-102. [CrossRef]

118. Aage, S.; Király, N.; Da Costa, K.; Byberg, S.; Bjerregaard-Andersen, M.; Fisker, A.B.; Aaby, P.; Benn, C.S. Neonatal vitamin A supplementation associated with increased atopy in girls. Allergy 2015, 70, 985-994. [CrossRef]

119. Diness, B.R.; Martins, C.L.; Balé, C.; Garly, M.-L.; Ravn, H.; Rodrigues, A.; Whittle, H.; Aaby, P.; Benn, C.S. The effect of high-dose vitamin A supplementation at birth on measles incidence during the first 12 months of life in boys and girls: An unplanned study within a randomised trial. Br. J. Nutr. 2011, 105, 1819-1822. [CrossRef]

120. Sommer, A. Vitamin A, infectious disease, and childhood mortality: A 2 cent solution? J. Infect. Dis. 1993, 167, 1003-1007. [CrossRef]

121. Hussey, G.D.; Klein, M. A randomized, controlled trial of vitamin a in children with severe measles. N. Engl. J. Med. 1990, 323, 160-164. [CrossRef] [PubMed]

122. Ellison, J.B. Intensive vitamin therapy in measles. BMJ 1932, 2, 708-711. [CrossRef] [PubMed] 
123. Bresee, J.S.; Fischer, M.; Dowell, S.F.; Johnston, B.D.; Biggs, V.M.; Levine, R.S.; Lingappa, J.R.; Keyserling, H.L.; Petersen, K.M.; Bak, J.R.; et al. Vitamin A therapy for children with respiratory syncytial virus infection: A multicenter trial in the United States. Pediatr. Infect. Dis. J. 1996, 15, 777-782. [CrossRef] [PubMed]

124. Fawzi, W.W.; Chalmers, T.C.; Herrera, M.G.; Mosteller, F. Vitamin A supplementation and child mortality. A meta-analysis. JAMA 1993, 269, 898-903. [CrossRef]

125. Villamor, E.; Fawzi, W.W. Effects of vitamin A supplementation on immune responses and correlation with clinical outcomes. Clin. Microbiol. Rev. 2005, 18, 446-464. [CrossRef]

126. Semba, R.D.; Munasir, Z.; Beeler, J.; Akib, A.; Muhilal; Audet, S.; Sommer, A. Reduced seroconversion to measles in infants given vitamin A with measles vaccination. Lancet 1995, 345, 1330-1332. [CrossRef]

127. Benn, C.S.; Aaby, P.; Balé, C.; Olsen, J.; Michaelsen, K.F.; George, E.; Whittle, H. Randomised trial of effect of vitamin A supplementation on antibody response to measles vaccine in Guinea-Bissau, west Africa. Lancet 1997, 350, 101-105. [CrossRef]

128. Kmieć, Z.; Myśliwska, J.; Rachoń, D.; Kotlarz, G.; Sworczak, K.; Myśliwski, A. Natural killer activity and thyroid hormone levels in young and elderly persons. Gerontol. 2001, 47, 282-288. [CrossRef]

129. Yaşar, P.; Ayaz, G.; User, S.D.; Güpür, G.; Muyan, M. Molecular mechanism of estrogen-estrogen receptor signaling. Reprod. Med. Biol. 2016, 16, 4-20. [CrossRef]

130. Weinberger, B.; Grubeck-Loebenstein, B. Vaccines for the elderly. Clin. Microbiol. Infect. 2012, 18 (Suppl. 5), 100-108. [CrossRef]

131. Solana, R.; Tarazona, R.; Gayoso, I.; Lesur, O.; Dupuis, G.; Fülöp, T. Innate immunosenescence: Effect of aging on cells and receptors of the innate immune system in humans. Semin. Immunol. 2012, 24, 331-341. [CrossRef] [PubMed]

132. Kumru, S.; Godekmerdan, A.; Yilmaz, B. Immune effects of surgical menopause and estrogen replacement therapy in peri-menopausal women. J. Reprod. Immunol. 2004, 63, 31-38. [CrossRef] [PubMed]

133. Ghosh, M.; Rodríguez-García, M.; Wira, C.R. The immune system in menopause: Pros and cons of hormone therapy. J. Steroid Biochem. Mol. Biol. 2013, 142, 171-175. [CrossRef] [PubMed]

134. Porter, V.R.; Greendale, G.A.; Schocken, M.; Zhu, X.; Effros, R.B. Immune effects of hormone replacement therapy in post-menopausal women. Exp. Gerontol. 2001, 36, 311-326. [CrossRef]

135. Ewies, A.A.; Alfhaily, F. Topical vaginal estrogen therapy in managing postmenopausal urinary symptoms: A reality or a gimmick? Climacteric 2010, 13, 405-418. [CrossRef] [PubMed]

136. Eimer, H.; Sureshkumar, S.; Singh Yadav, A.; Kraupner-Taylor, C.; Bandaranayake, C.; Seleznev, A.; Thomason, T.; Fletcher, S.J.; Gordon, S.F.; Carroll, B.J.; et al. RNA-dependent epigenetic silencing directs transcriptional downregulation caused by intronic repeat expansions. Cell 2018, 174, 1095-1105.e11. [CrossRef]

137. Wang, L.H.; Yang, X.Y.; Zhang, X.; Mihalic, K.; Xiao, W.; Farrar, W.L. The cis decoy against the estrogen response element suppresses breast cancer cells via target disrupting c-fos not mitogen-activated protein kinase activity. Cancer Res. 2003, 63, 2046-2051.

138. Cabrini, G.; Bezzerri, V.; Mancini, I.; Nicolis, E.; Dechecchi, M.C.; Tamanini, A.; Lampronti, I.; Piccagli, L.; Bianchi, N.; Borgatti, M.; et al. Targeting transcription factor activity as a strategy to inhibit pro-inflammatory genes involved in cystic fibrosis: Decoy oligonucleotides and low-molecular weight compounds. Curr. Med. Chem. 2010, 17, 4392-4404. [CrossRef]

139. Gambari, R. Recent patents on therapeutic applications of the transcription factor decoy approach. Expert Opin. Ther. Pat. 2011, 21, 1755-1771. [CrossRef]

140. Hecker, M.; Wagner, A.H. Transcription factor decoy technology: A therapeutic update. Biochem. Pharmacol. 2017, 144, 29-34. [CrossRef]

141. Rad, S.M.; Langroudi, L.; Kouhkan, F.; Yazdani, L.; Koupaee, A.N.; Asgharpour, S.; Shojaei, Z.; Bamdad, T.; Arefian, E. Transcription factor decoy: A pre-transcriptional approach for gene downregulation purpose in cancer. Tumor Biol. 2015, 36, 4871-4881. [CrossRef] [PubMed]

142. Dias, N.; Stein, C.A. Antisense oligonucleotides: Basic concepts and mechanisms. Mol. Cancer Ther. 2002, 1, 347-355. [PubMed]

143. Barolo, S. How to tune an enhancer. Proc. Natl. Acad. Sci. USA 2016, 113, 6330-6331. [CrossRef] [PubMed]

144. Rao, V.K.; Kapp, D.; Schroth, M. Gene therapy for spinal muscular atrophy: An emerging treatment option for a devastating disease. J. Manag. Care Spec. Pharm. 2018, 24, S3-S16. [CrossRef] 
145. Bennett, C.F.; Baker, B.F.; Pham, N.; Swayze, E.; Geary, R.S. Pharmacology of antisense drugs. Annu. Rev. Pharmacol. Toxicol. 2017, 57, 81-105. [CrossRef]

146. Shin, H.Y. Targeting super-enhancers for disease treatment and diagnosis. Mol. Cells 2018, 41, 506-514. [CrossRef]

147. Callaway, E. CRISPR cuts turn gels into biological watchdogs. Nature 2019, 572, 574. [CrossRef]

148. Aguiar, S.; Dias, J.; Manuel, A.M.; Russo, R.; Gois, P.M.P.; Da Silva, F.A.; Goncalves, J. Chimeric small antibody fragments as strategy to deliver therapeutic payloads. Adv. Protein Chem. Struct. Biol. 2018, 112, 143-182. [CrossRef]

149. Erwin, G.S.; Grieshop, M.P.; Ali, A.; Qi, J.; Lawlor, M.; Kumar, D.; Ahmad, I.; McNally, A.; Teider, N.; Worringer, K.; et al. Synthetic transcription elongation factors license transcription across repressive chromatin. Science 2017, 358, 1617-1622. [CrossRef]

(C) 2020 by the authors. Licensee MDPI, Basel, Switzerland. This article is an open access article distributed under the terms and conditions of the Creative Commons Attribution (CC BY) license (http://creativecommons.org/licenses/by/4.0/). 